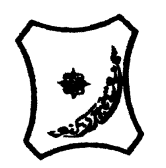

Bayero Journal of Pure and Applied Sciences, 12(1):1 - 5

Received: March, 2018

Accepted: December, 2018

ISSN $2006-6996$

\title{
ENHANCED OPTICAL TRANSMITTANCE OF SPRAY DEPOSITED ZINC OXIDE THIN FILMS FOR OPTOELECTRONIC APPLICATIONS
}

\author{
Adam, A. A., ${ }^{1 *}$ Musa, M. $^{2}$ and Sani, M. $^{3}$ \\ ${ }^{1,3}$ Department of Physics, College of Natural and Applied Sciences, Al-Qalam University, Katsina. \\ P.M.B 2137, Katsina, Nigeria. \\ ${ }^{2}$ Department of Physics, Faculty of Science, Nigeria Police Academy, Wudil. P.M.B. 3474, Kano, \\ Nigeria. \\ *Corresponding author: ibneeabdullah234@gmail.com,abdullahiaadam@auk.edu.ng
}

\begin{abstract}
Transparent zinc oxide thin films (undoped and Mo doped) were coated on glass substrates at the substrate temperature of $400^{\circ} \mathrm{C}$ using spray pyrolysis set up. The various Mo doping concentrations for the Mo doped thin films are $0.25 w t . \%, 0.5 w t \%$, $0.75 w t . \%$ and 1 wt. \%. Prepared thin films were characterized by X-ray Diffraction (XRD) and UV-Vis Spectroscopy techniques. Thicknesses of the prepared films were determined using gravimetric method. XRD of the films shows that ZnO belongs to the hexagonal wurtzite structure. Preferred growth orientation for undoped and Mo doped ZnO thin films is along (002) direction, except for the 0.5wt.\%Mo:Zno thin film where the (101) peak becomes prominent. The XRD intensity of the (002) peak decreases with increasing Mo doping concentration for $0.25 w t . \%$ and $0.5 w t . \%$, after which it increases for $0.75 w t . \%$ and $1 w t . \%$. Crystallite sizes and lattice parameters for the ZnO and Mo:ZnO thin films were also evaluated. Optical studies of the prepared films show an average visible transmittance (AVT) of about $88 \%$ recorded in the $380 \mathrm{~nm}$ to $800 \mathrm{~nm}$ wavelength region. Optical bandgap for all the films were also reported. Slight increase in the bandgap of ZnO is observed with increasing Mo doping concentration.
\end{abstract}

Keywords: average visible transmittance, spray pyrolysis, thin films, lattice parameters, optical bandgap.

\section{INTRODUCTION}

Over the years, there has been increasing demand in low cost transparent conductive oxides (TCO) films, due to their optoelectronic properties in such devices as light emitting diodes, flat panel displays, window layers in heterojunction solar cells, heat mirrors e.t.c. (Mohammad et al, 2006; Swapna and Kumar, 2013). ZnO is one of the promising TCO due to its direct and wide bandgap (about $3.37 \mathrm{eV}$ ) and large exciton binding energy (about $60 \mathrm{meV}$ at $300 \mathrm{~K}$ ), low cost, good optical and piezoelectric behavior compared to other TCO like ITO, $\mathrm{SnO}_{3}$, $\mathrm{Cd}_{2} \mathrm{SnO}_{4}$ (Souissi et al, 2014; Bougarine et al, 2003). ZnO thin films can be prepared by various techniques, some of which include pulsed laser deposition (Cao et al, 2011), magnetron sputtering(Yoon et al, 2008), sol gel dip coating (Ramesh et al, 2013), reactive electron beam evaporation (Iqbal et al, 2013), sol gel spin coating (Thambidurai, 2014) and spray pyrolysis (Gokulakrishnan et al, 2011; Jagadesh and Pearton, 2006; Benramache et al, A very small amount of Mo doping can possibly give enough free carriers in the $\mathrm{ZnO}$ film because of the high valence difference between
2014; Swapna and Kumar, 2012; Gokulakrishnan et al., 2011).

Although $\mathrm{ZnO}$ has a high transparency, it equally has a low conductivity. Reports have shown that doping $\mathrm{ZnO}$ with various impurity materials at different doping levels in the film can lead to improved electrical conductivity without compromising optical transmittance. For instance zirconium doping showed a lowest resistivity of $2 \times 10^{-3} \Omega \mathrm{cm}$ at $3 \mathrm{wt} \%$ (Gokulakrishnan et al., 2011), doping of cobalt showed a conductivity of $9.27(\Omega \mathrm{cm})^{-1}$ at $2 \mathrm{wt} \%$ (Swapna and Kumar, 2012) and doping of molybdenum showed a resistivity of $6.22 \times 10^{-}$ ${ }^{2} \Omega \mathrm{cm}$ (Benramache et al., 2014). In Mo doped $\mathrm{ZnO}$, Mo either substitutes $\mathrm{Zn}$ in the host matrix or it acts as an interstitial atom. The substitution of $\mathrm{Zn}$ with $\mathrm{Mo}$ is possible due to smaller radius of Mo $(0.062 \mathrm{~nm})$ compared to $\mathrm{Zn}(0.083 \mathrm{~nm})$ (Swapna and Kumar, 2012).

In the present work we investigated the effect of very low Mo doping concentrations in $\mathrm{ZnO}$ film deposited using spray pyrolysis set up. $\mathrm{Mo}^{6+}$ and $\mathrm{Zn}^{2+}$. Therefore $\mathrm{Mo}\left([\mathrm{Kr}]: 4 \mathrm{~d}^{5} 5 \mathrm{~s}^{1}\right)$ can donate four electrons to the free carriers in the $\mathrm{ZnO}$ matrix. The spray pyrolysis technique in 
BAJOPAS Volume 12 Number 1, June, 2019

comparison to other chemical deposition techniques has several advantages such as high purity and excellent control of chemical uniformity in multi-component system. Deposited films were subjected to various characterization studies in order to investigate the doping effects on the structural and optical properties of the films.

\section{Experimental detail}

Pure $\mathrm{ZnO}$ and Mo doped $\mathrm{ZnO}$ thin films were coated on glass substrates at $400^{\circ} \mathrm{C}$ by spray pyrolysis method. A homogenous solution was obtaind by dissolving $0.1 \mathrm{M}$ zinc acetate dihydrate $\left(\mathrm{Zn}\left(\mathrm{CH}_{3} \mathrm{COOH}\right)_{2} \cdot 2 \mathrm{H}_{2} \mathrm{O}\right)$ and ammonium heptamolybdate $\left(\left(\mathrm{NH}_{4}\right)_{6} \mathrm{Mo}_{7} \mathrm{O}_{24} \cdot 4 \mathrm{H}_{2} \mathrm{O}\right)$ in double distilled water and methanol (in the ratio $3: 1$ ) using compressed air as carrier gas. As explained in our previous work, the following optimization set up was maintained throughout the experiments; the spray nozzle-substrate distance $(25 \mathrm{~cm})$, spray angle $\left(45^{\circ}\right)$, carrier gas pressure $\left(40 \mathrm{Kgcm}^{-2}\right)$, spray time (1sec) and spray interval (20sec) (Abdullahi et al, 2015; Abdullahi and Ramamurthi, 2015).

Structural properties of the prepared films were studied PANalytical X'Pert PRO X-ray diffractometer (CuKa radiation, $\lambda=1.5405 \AA$ ), $2 \theta$ range of $0^{\circ}-90^{\circ}$. Optical properties of the deposited films were investigated using double beam spectrophotometer (Ocean Optics) in the wavelength range of $300-1000 \mathrm{~nm}$.

\section{RESULTS AND DISCUSSION Structural studies}

Fig. 1 shows the X-ray diffraction patterns for $\mathrm{ZnO}$ and Mo:ZnO thin films. The JCPDS card no. 89-1397 confirms that the films belong to the hexagonal wurtzite structure with (002) preferential orientation. The undopedZnO film has (002) peak corresponding to $2 \theta=34.30^{\circ}$ as the highest peak intensity followed by the (101) peak corresponding to $2 \theta=36.08^{\circ}$. Other peaks include the (102), (110), (103) and (113) diffraction. The (002) peak intensity decreases with increase in the Mo doping concentration from 0.25 wt. $\%$ to 0.5 wt. $\%$. It then increases progressively for $0.75 \mathrm{wt} . \%$ and $1 \mathrm{wt} . \%$. The intensity of the (002) is maximum for $1 w t . \%$ compared to other doping concentrations. All peaks seen in the XRD pattern belong to $\mathrm{ZnO}$ as confirmed from the JCPDS card number stated above.

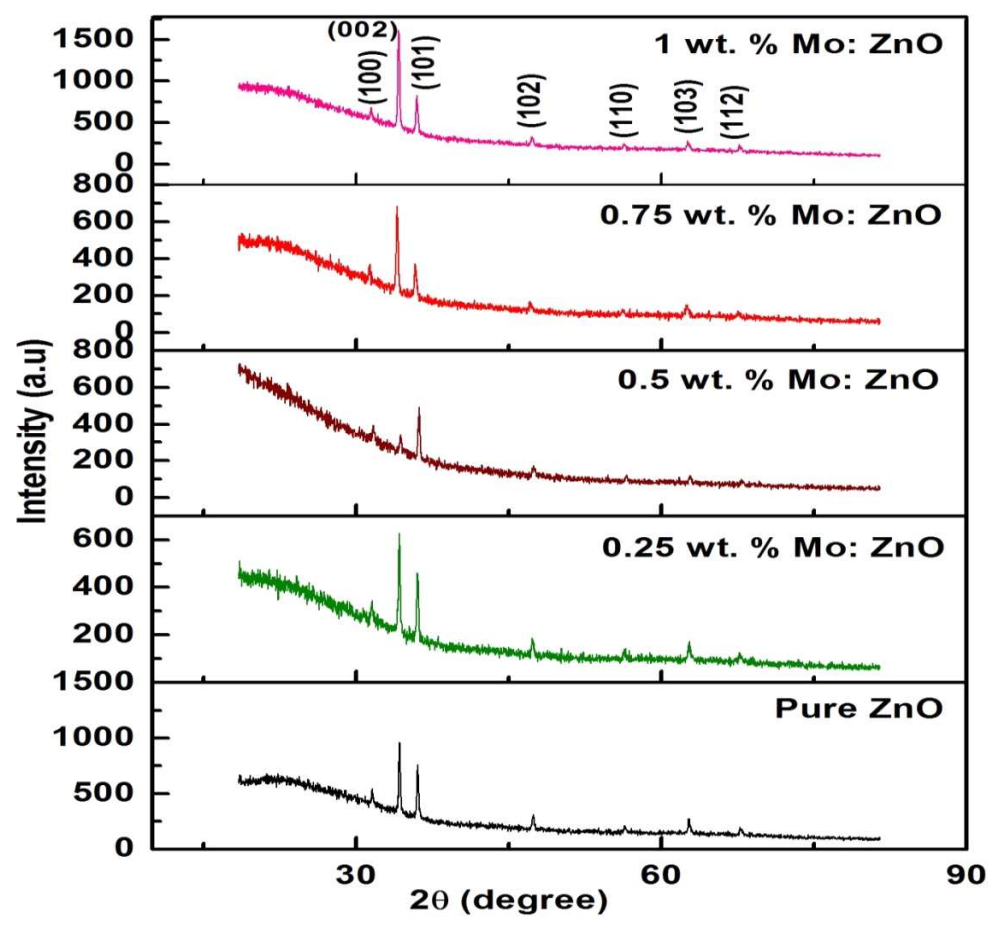

Fig.1. XRD patterns of undoped and Mo doped ZnO thin films. 
BAJOPAS Volume 12 Number 1, June, 2019

The lattice parameters ' $a$ ' and ' $c$ ' of the deposited $\mathrm{ZnO}$ and $\mathrm{Mo:ZnO}$ thin films were estimated from (002) and (001) XRD peaks respectively and are presented in Table 1 . A slight change in the ' $a$ ' and ' $c$ ' values is due to the change in the $2 \theta$ values of the peaks. Thus molybdenum incorporation into the $\mathrm{ZnO}$ matrix leads to a slight change in the lattice parameters. Crystallite size of the deposited thin films were obtained from Scherrer's formula (Cullity, 1967).

$D=\frac{C \lambda}{\beta \cos \theta}$

Where $C$ is correction factor $(0.9), \lambda$ is the wavelength of $X$-rays $(\lambda=1.5405 \AA)$ and $\beta$ is the full width half maximum (in radian). The crystallite size calculated from the (002) peak of the deposited Mo:ZnO thin films varies with doping concentration from $\sim 32.6 \mathrm{~nm}$ to $45.1 \mathrm{~nm}$. The lattice parameters for the hexagonal structure are obtain from the formula(Abdullahi et al, 2015).

$\frac{1}{d^{2}}=\frac{4}{3}\left(\frac{h^{2}+h k+k^{2}}{a^{2}}\right)+\frac{l^{2}}{c^{2}}$

where $d$ is the interplaner distance and $(h k l)$ refers to the Miller indices.

The interplanaer distance is calculated using the Bragg's relation for first order reflection (Gokulakrishnan et al, 2011).

$d=\frac{\lambda}{2 \sin \theta}$

where $\theta$ is the glancing angle.

Table 1: Structural parameters for $\mathrm{ZnO}$ and Mo:ZnO thin films for (002) peak

\begin{tabular}{|c|c|c|c|c|c|c|}
\hline \multirow[t]{2}{*}{$\begin{array}{l}\text { Mo:ZnO } \\
\text { (wt. \%) }\end{array}$} & \multirow[t]{2}{*}{$\begin{array}{l}2 \theta \\
\left({ }^{\circ}\right)\end{array}$} & \multirow[t]{2}{*}{$\begin{array}{c}\text { FWHM } \\
\left({ }^{\circ}\right)\end{array}$} & \multirow[t]{2}{*}{$\begin{array}{c}\text { d - spacing } \\
(\AA)\end{array}$} & \multirow[t]{2}{*}{$\underset{(\mathrm{nm})}{D}$} & \multicolumn{2}{|c|}{$\begin{array}{l}\text { Lattice Parameter } \\
\text { ( }(\AA)\end{array}$} \\
\hline & & & & & $a$ & $c$ \\
\hline 0 & 34.30 & 0.18 & 2.61 & 45.08 & 3.27 & 5.22 \\
\hline 0.25 & 34.28 & 0.19 & 2.61 & 44.57 & 3.27 & 5.23 \\
\hline 0.50 & 34.42 & 0.26 & 2.60 & 32.58 & 3.25 & 5.21 \\
\hline 0.75 & 34.16 & 0.22 & 2.62 & 38.12 & 3.29 & 5.24 \\
\hline 1.00 & 34.23 & 0.20 & 2.62 & 42.50 & 3.27 & 5.23 \\
\hline
\end{tabular}

Optical studies

Figure 2 shows the optical transmittance of $\mathrm{ZnO}$ and Mo:ZnO thin films in the range $200-1200 \mathrm{~nm}$ of wavelength. An average visible transmittance (AVT) of about $88 \%$ is recorded in the $380 \mathrm{~nm}$ $800 \mathrm{~nm}$ wavelength region. Increase in the transmittance is observed with an increase in Mo doping concentration (Table 2). Absorption coefficient for the deposited films is calculated using the relation (Gokulakrishnan et al, 2011).

$\alpha=\frac{1}{t} \ln \left(\frac{1}{T}\right)$

where $t$ is the film thickness and $T$ is the transmittance of the film.

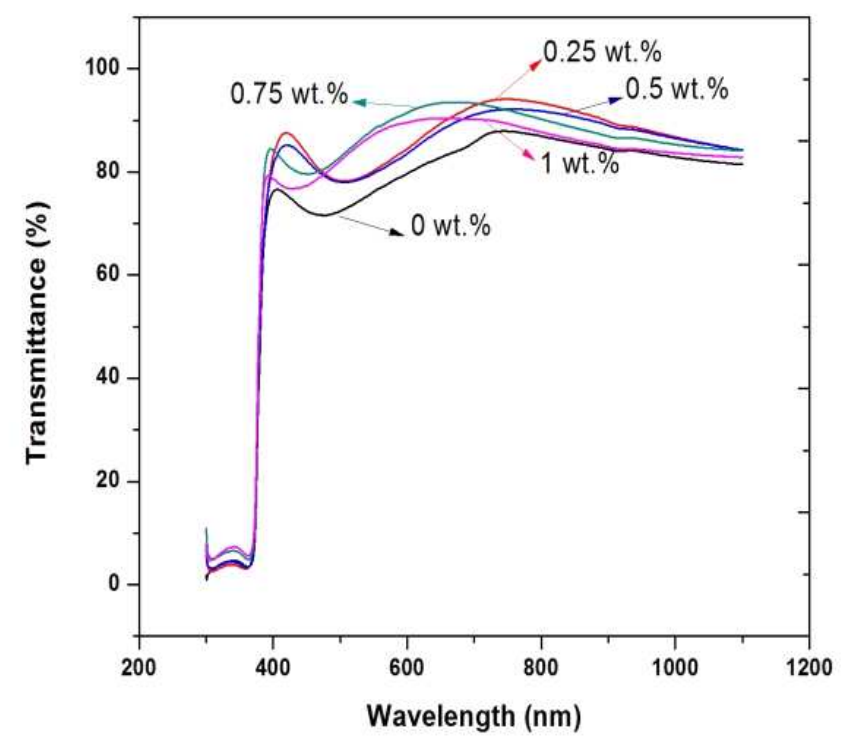

Figure 2: Optical transmittance of $\mathrm{ZnO}$ and Mo:ZnO thin films 
BAJOPAS Volume 12 Number 1, June, 2019

Table 2: Average and maximum transmittance of $\mathrm{ZnO}$ and Mo:ZnO thin films.

\begin{tabular}{ccc}
\hline $\begin{array}{c}\text { Mo doping Co } \\
\text { concentration } \\
\text { (wt.\%) }\end{array}$ & $\begin{array}{c}\text { Average Visible } \\
\text { transmittance (\%) } \\
\text { 380nm-800nm }\end{array}$ & $\begin{array}{c}\text { Maximum Optical } \\
\text { transmittance (\%) }\end{array}$ \\
0 & 79.90 & $88(700 \mathrm{~nm})$ \\
0.25 & 86.66 & $95(750 \mathrm{~nm})$ \\
0.50 & 85.42 & $90(750 \mathrm{~nm})$ \\
0.75 & 88.46 & $94(650 \mathrm{~nm})$ \\
1.00 & 86.15 & $89(650 \mathrm{~nm})$ \\
\hline
\end{tabular}

The direct bandgap of the films is obtained using the formula (Gokulakrishnan et al, 2011).

$$
\alpha h v=B\left(h v-E_{g}\right)^{1 / 2}
$$

where $h v$ is the photon energy, $E_{g}$ is the optical bandgap and $B$ is a constant.

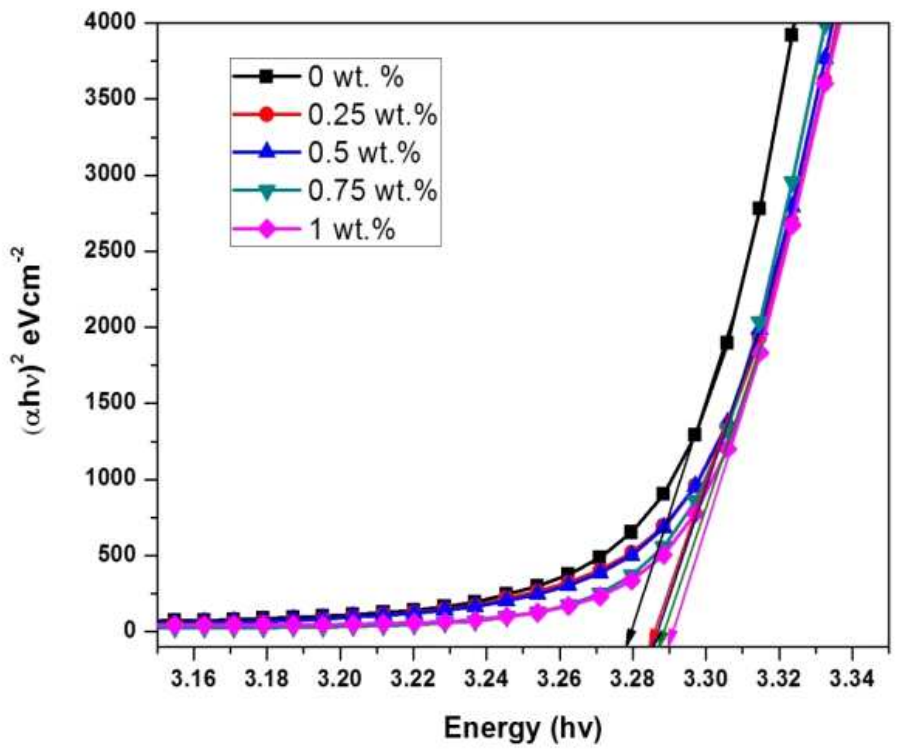

Figure 3: Optical bandgap values for ZnO and Mo:ZnO thin films

Table 3 Optical bandgap values for ZnO and Mo:ZnO thin films.

\begin{tabular}{cccccc}
$\begin{array}{c}\text { Mo doping } \\
\text { Concentration } \\
\text { (wt.\%) }\end{array}$ & 0 & 0.25 & 0.50 & 0.75 & 1.00 \\
$\begin{array}{c}\text { Optical } \\
\text { Bandgap } \\
\text { (eV) }\end{array}$ & 3.278 & 3.285 & 3.286 & 3.288 & 3.290 \\
\hline
\end{tabular}

Though Mo doping does not appreciably change the optical bandgap of the ZnO film, a slight increase is observed with increasing Mo doping level.

\section{CONCLUSION}

Pure $\mathrm{ZnO}$ and molybdenum doped zinc oxide thin films were coated on glass slide at $400^{\circ} \mathrm{C}$ using spray pyrolysis method. XRD pattern for the deposited films show a (002) preferred growth orientation. The intensity of the (002) peak initially decreases with Mo doping level up to 0.5 wt. $\%$, after which it increases for 0.75 and 1 wt.\% Mo doping concentration. All peaks are due to $\mathrm{ZnO}$. The films belong to the hexagonal wurtzite structure of ZnO. UV-Vis spectra show an average visible transmittance (AVT) of about $88 \%$ recorded in the $380 \mathrm{~nm}$ $800 \mathrm{~nm}$ wavelength region. Also a slight increase in the bandgap of $\mathrm{ZnO}$ is observed with increasing Mo concentration. 
BAJOPAS Volume 12 Number 1, June, 2019

\section{REFERENCES}

Mohammad M.T., Hashim A.A. and Al-Maamory M.H.(2006). Highly conductive and transparent $\mathrm{ZnO}$ thin films prepared by spray pyrolysis technique,Mater. Chem. and Phy., 99, 382-387.

Swapna R., Kumar M.C.S.(2013). Growth and characterization of molybdenum doped $\mathrm{ZnO}$ thin films by spray pyrolysis, J. Phys. Chem. Solids, 74, 418-425.

Souissi A., Boukhachem A., Ben Taher Y., Ayadi A., Mefteh A., Ouesleti M., Guermazia S. and Amlouk M.(2014). Structural and vibrational studies of Mo and In doped ZnO sprayed thin films, Optik, 125, 33443349.

Bougarine A., EL Hichou A., Abdou M., Ebothe J., Kachouane A. and Troyon M.(2003)Structural, optical and cathodoluminescence characteristics of undoped and tin doped ZnOthin films prepared by spray pyrolysis, Mater. Chem. and Phy., 80, 438-445.

Cao L., Zhu L., Jiang J., Zhao R., Ye Z. and Zhao B.(2011). Highly transparent andconducting fluorine-doped $\mathrm{ZnO}$ thin films prepared by pulsed laser deposition, Sol. Energy Mater. \& Sol. Cells, 95, 894898.

Yoon H.S., Lee K.S., Lee T.S., Cheong B., Choi D.K., Kim D.H. and Kim W.M.,(2008). Properties of fluorine doped $\mathrm{ZnO}$ thin films deposited by magnetron sputtering, Sol. Energy Mater. \& Sol. Cells, 92, 1366-1372, 2008.

Ramesh J., Pasupathi G., Mariappan R., Kumar V.S. and Ponnuswamy V.(2013). Structural and optical properties of $\mathrm{Ni}$ doped $\mathrm{ZnO}$ thin films using sol-gel dip coating technique,Optik, 124, 2023-2027.

Iqbal A., Mahmood A., Khan T. M. and Ahmed E.(2013). Structural and optical properties of $\mathrm{Cr}$ doped $\mathrm{ZnO}$ crystalline thin films deposited by reactive beam evaporation technique, Prog. Nat. Sci:Mat. Int., 23, 64-69.

Thambidurai M., Kim J. Y., Song J., Ko Y., Muthukumarasamy N., Velauthapillai D. and Lee C.(2014).NanocrystallineGa doped $\mathrm{ZnO}$ thin films for inverted polymer solar cells, Sol. Energy, 106, 95-101.

Gokulakrishnan V., Parthiban S., Jeganathan K. and Ramamurthi K.(2011).Investigation on the effect of $\mathrm{Zr}$ doping in $\mathrm{ZnO}$ thin films by spray pyrolysis, Appl. Surf. Sci., 257, 9068-9072.

Jagadesh C. and Pearton S.J.(2006).Zinc oxide bulk, thin films and nanostructures; processing, properties and applications, Elsevier, Amsterdam.

Benramache S., Rahal A. and Benhaoua B.(2014). Effects of solvent nature on spray deposited $\mathrm{ZnO}$ thin films prepared from $\mathrm{Zn}\left(\mathrm{CH}_{3} \mathrm{COO}\right)_{2} .2 \mathrm{H}_{2} \mathrm{O}$, Optik, vol.125, 1816-1820.

Swapna R. and Kumar M.C.S.(2012). The role of substrate temperature on the properties of nanocrystalline Mo doped $\mathrm{ZnO}$ thin films by spray pyrolysis, Ceram. Int., 38 , 3875-3883.

Gokulakrishnan V., Parthiban S., Jeganathan K. and Ramamurthi K.(2011). Investigation of molybdenum doped $\mathrm{ZnO}$ thin films prepared by spray pyrolysis technique, Ferroelectrics, 423, 126-134.

Abdullahi A. A., Ramamurthi K. and Mahesh M.(2015). Studies on the influence of Mo doping the structural, morphological and optical properties of spray pyrolyticZnO thin films, International Journal Adv. Chem. Sci. and Applns., 3(2), 51-56.

Abdullahi A. A. and Ramamurthi K.(2015). Effects of solvent on the structural and optical properties of spray deposited zinc oxide thin films, International Journal Adv. Chem. Sci. and Applns.,3(3), 7-11.

Cullity B.D.(1967). Elements of X-ray Diffraction, Addison, Wesley Publication Co. 